\title{
The Sargassum Frogfish (Histrio histrio Linnaeus) observed in mangroves in St. John, US Virgin Islands
}

Received: 6 April 2010/Accepted: 3 May 2010/Published online: 18 June 2010

(C) US Government 2010

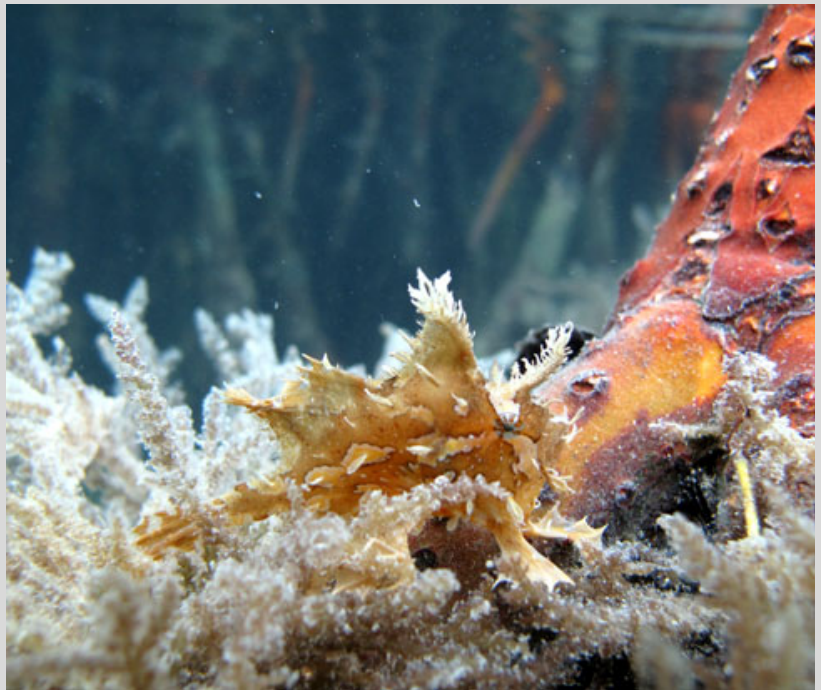

Fig. 1 A Sargassum Frogfish in Acanthophora spicifera on a mangrove prop root
The Sargassum Frogfish (Histrio histrio), the only pelagic member of the frogfish family Antennariidae, is considered an obligate associate of floating mats of the brown algae Sargassum natans and S. fluitans (Adams 1960; Dooley 1972; Pietsch and Grobecker 1987). Between February and April 2010, 20 of these fish were observed in three mangrove-fringed bays in Virgin Islands Coral Reef National Monument, St. John, US Virgin Islands. All of them were clinging to clumps of the red alga Acanthophora spicifera growing on the submerged prop roots of red mangrove trees (Rhizophora mangle) distributed along an estimated total of $2,160 \mathrm{~m}$ of shoreline (Fig. 1). All of the fish were at a depth of less than 0.5 meters. Two individuals were seen on one prop root, but the other 18 were solitary. Their estimated standard lengths ranged from about 20 to $100 \mathrm{~mm}$. Littler and Littler (2000, p. 295) published a photograph of one individual in blades of the green alga Ulva lactuca growing on a prop root in Belize. This is the first report of the Sargassum Frogfish living in association with attached algae.

\section{References}

Adams JA (1960) A contribution to the biology and postlarval development of the Sargassum fish, Histrio histrio (Linnaeus), with a discussion of the Sargassum complex. Bull Mar Sci Gulf Caribb 10:55-82

Dooley JK (1972) Fishes associated with the pelagic Sargassum complex, with a discussion of the Sargassum community. Contributions in Marine Science 16:1-32

Littler DS, Littler MM (2000) Caribbean reef plants. Offshore Graphics Inc, Washington, DC, p 542

Pietsch TW, Grobecker DB (1987) Frogfishes of the world. Stanford University Press, Stanford, CA, p 420

C. S. Rogers $(\square)$

US Geological Survey, Southeast Ecological Science Center, Caribbean Field Station, 1300 Cruz Bay Creek, St. John, USVI 00830, USA

e-mail: caroline_rogers@usgs.gov

T. W. Pietsch · R. J. Arnold

School of Aquatic and Fishery Sciences, University of Washington, 1122 NE Boat St., Box 355020, Seattle, WA 98195, USA

J. E. Randall

Bishop Museum, 1525 Bernice St., Honolulu, HI 96817, USA 